\title{
Water for Energy: Inconsistent Assessment Standards and Inability to Judge Properly
}

\author{
Kaveh Madani $\cdot$ Sina Khatami
}

Published online: 18 January 2015

(C) Springer International Publishing AG 2015

\begin{abstract}
The water-energy nexus field is experiencing growing attention to assessing the impacts of energy generation on water resources. Numerous studies in recent years have used a range of metrics and methods for measuring and quantifying the water impacts of energy. This article argues that the field is suffering from a lack of consistency in the interpretation and application of different evaluation metrics due to competition for the development of the 'correct' evaluation method. The uncertainties caused by inconsistent analysis methods, assumptions, scales and boundaries make the available information confusing and hamper our abilities to understand comprehensively and judge properly. The article highlights some of the major caveats that need to be considered in using the results of the previous studies and applying the existing metrics for evaluating the impacts of energy production on water resources.
\end{abstract}

Keywords Water · Energy $\cdot$ Water-energy nexus $\cdot$ Virtual water - Water footprint $\cdot$ Water use $\cdot$ Water consumption . Water withdrawal $\cdot$ Water abstraction $\cdot$ Blue water $\cdot$ Green water - Gray water - Method · Evaluation - Analysis . Measurement · Assessment · Evaluation · Standard · Metric

This article is part of the Topical Collection on Energy-Water Nexus

K. Madani $(\bowtie)$

Centre for Environmental Policy, Imperial College London,

14 Prince's Gardens, London SW7 1NA, UK

e-mail: k.madani@imperial.ac.uk

S. Khatami

Department of Infrastructure Engineering, The University of

Melbourne, Parkville, VIC, Australia

\section{Introduction}

Energy and water are firmly interconnected and interdependent. We need energy to purify, desalinate and transfer water. On the other hand, energy production, whatever the source is, consumes and impacts water. Water is used in energy mining and production, running turbines, cooling power plants, construction and operation of energy generation facilities, and disposing their waste products $[1,2 \bullet \bullet, 3,4 \bullet \bullet]$. This reciprocal dependency of water and energy is the core idea of the waterenergy nexus.

Since a few decades ago, the strong parallel between the burgeoning water and energy scarcity grew into an important discussion in the literature. Undeniably, energy and water demands are rapidly increasing due to economic development, population increase and growth of the middle class in the developing world [5]. However, freshwater supplies are diminishing in many regions due to climatic changes, more frequent droughts and the escalated competition over available water resources between the energy and agricultural sectors. Thus, the water-energy nexus discussion has heated up even more seriously in recent years and has sprawled across a wider range, encouraging the investigation of different aspects of the water-energy nexus and its connections with other sectors or resources. Examples include research on energy recovery from water and wastewater reuse [6-8], energy intensity of water operations [9-11, 12••, 13], water intensity of transportation $[14 \cdot, 15 \bullet, 16]$, water impacts of electricity generation $[12 \bullet \bullet, 17,18 \bullet, 19,20,21 \bullet]$, water footprint of energies $[2 \bullet \bullet, 22$, 23.], policy and the institutional aspects of the water-energy nexus [24-26], water-energy-food nexus [27-31], water-foodenergy-climate nexus [32] and water-energy-climate-landeconomy nexus $[33,34,35 \cdot]$.

By focusing on the 'water for energy' side of the waterenergy nexus, this article intends to highlight the major methodological gaps in the field that limit our capacity for the 
holistic evaluation of the impacts of the energy sector on water resources. It is argued that the existing inconsistencies between the different evaluation approaches and metrics can create superfluous uncertainties that would be confusing to decision makers, hampering their ability to develop sustainable solutions that can solve the emergent energy problems without having unintended impacts on water resources.

\section{Thirsty Energy}

By 2035 , global energy use is expected to rise by $35-40 \%$ $[36,37 \bullet \bullet]$, with China, India and the Middle East being responsible for $60 \%$ of this increase [38]. During this time, electricity demand will increase by $70 \%$ [38]. By mid-century, electricity generation in Africa, Latin America and Asia is expected to increase by $700 \%, 500 \%$ and $200 \%$, respectively [39]. Emerging economies such as Brazil, China and India are expected to double their energy consumption within the next four decades [39]. The increasing energy demand will impose extra pressure on the already stressed water resources that in the meantime must be used to increase agricultural production by $60 \%$ to feed the world's growing population [40].

Estimates of the water impacts of energy generation are different due to different assumptions, projections, and evaluation methods/standards [2••]. The International Energy Agency (IEA) estimates that the global water withdrawals for energy production in 2010 were at 583 billion $\mathrm{m}^{3}(15 \%$ of global water withdrawals, exceeding the average annual discharge of India's Ganges River), of which 66 billion $\mathrm{m}^{3}$ was consumed [41••]. Based on the IEA estimates, by 2035 water withdrawals could increase by $20 \%$, while water consumption is expected to increase by $85 \%$. These changes are due to the wider use of higher efficiency power plants with more advanced cooling systems, which reduce water withdrawals at the expense of increased consumption, and to the increased production of biofuel [38], with a water footprint that is 70-400 times larger than that of conventional fossil energies [22]. Carbon capture and storage and expansion of nuclear facilities [42•], as well as increased hydraulic fracturing (fracking) and shale gas production [2••, 43-48], have been recognized as the other possible causes of increased water withdrawals in the future.

Thermal power plants produce $80 \%$ of global electricity $[38,42 \cdot]$ while having a significant water consumption rate $[21 \bullet]$. The water used for cooling purposes dominates the lifecycle water use of electricity generation $[21 \bullet]$ and is responsible for $50 \%$ and $43 \%$ of freshwater withdrawals in the US and Europe, respectively [38]. Global water withdrawals for thermal electricity generation are expected to increase by $40 \%$ by mid-century [38], while water consumption for electricity generation is expected to more than double in this period [39].
A recent study of the water footprint of the energy supply portfolios based on energy production and consumption scenarios in the International Energy Outlook of the US Energy Information Administration (EIA) suggests an increase of $37-$ $66 \%$ in the global water footprint of the energy sector by 2035 $[2 \cdot \bullet]$. While this increase can be mainly attributed to the world's growing energy demand, the study suggests that the water required per unit of produced energy will likely increase by $5-10 \%$, depending on future oil prices. Higher oil prices would encourage a faster shift toward some renewables [49] that can be more water-intensive than today's fossil fuels [2••, $22,50,51]$.

The energy sector's pressure on water resources has a reinforcing effect that has not been comprehensively examined. Increased energy demand, in addition to growing food demand, make water resources more scarce. The shortage of water normally encourages interbasin water transfers [52], more aggressive use of groundwater resources [53-56], and increased desalination and wastewater reuse [12••]. These energy-intensive water management approaches would further increase the water need of energy. Climate change is expected to exacerbate the situation by limiting the potential for production of certain energies such as hydroelectricity [57-59], increasing energy demands in some parts of the world [60] and decreasing water productivity in the agricultural sector [61-63], which would further increase the need for water and energy within the next decades.

While future projections of the water impacts of energy might be different, they all agree on one fact - the energy sector would become thirstier, imposing extra pressure on the managers of water and energy resources who have conventionally operated independently despite the high interdependence of the resources they manage. There is a serious need for balancing the trade-offs between the different aspects of water-energy nexus management. However, a successful balance requires a good understanding of the possible effects of different policy options. We argue that the current state of the art in this field is not sufficiently mature, failing to provide digestible information that can properly guide decision making to operate and develop sustainably.

\section{Multiple Metrics and Inconsistent Applications}

Interest in evaluating energy production impacts on water has increased over the years, as indicated by the growing literature on this subject. While this is a positive sign at first glance, and reflects having a more water-cautious research community, the inconsistency between the methods used and the competition over developing and applying a 'superior' method of evaluation limits the meaningful progress in this field.

The 'water for energy' literature has developed and used numerous metrics for measuring the water impacts of energy 
production, including, but not limited to, water withdrawal, water consumption, water utilization, water use, virtual water content, water footprint, blue water, green water, gray water, water abstraction, freshwater use, consumptive water use, instream freshwater degradative use, in-stream freshwater consumptive use, off-stream freshwater degradative use, offstream freshwater consumptive use, water productivity, withdrawal to availability (WTA) ratio, normalized water consumption, water withdrawal footprint, water availability time-span, eco factor, water stress indicator, and characterization factor $[1,2 \bullet \bullet, 14 \bullet, 15 \bullet, 16,17,18 \bullet, 19,20,21 \bullet, 22,23 \bullet$, $39,41 \bullet \bullet, 42 \bullet, 51,64-66,67 \bullet \bullet, 68-77,78 \bullet]$. In theory, these metrics are valuable, complementary and informative; however, the inconsistency in their interpretation and application has resulted in incomparable and sometimes contradictory results.

We believe that consideration of the following caveats is necessary in the assessment of the impacts of energy production on water resources using the available metrics and methods in the literature.

a. The energy's water impact metrics have unique definitions and must not be used interchangeably. Table 1 provides the standard definitions of the most commonly used metrics for quantifying the impacts of energy production on water resources. The existing literature suggests that the

Table 1 Most commonly used metrics for evaluating the impacts of energy production on water resources

\begin{tabular}{|c|c|}
\hline Metric & Definition \\
\hline $\begin{array}{l}\text { Water } \\
\text { withdrawal }\end{array}$ & $\begin{array}{l}\text { The total freshwater (surface water and groundwater) } \\
\text { input into the energy production system }\end{array}$ \\
\hline $\begin{array}{l}\text { Water } \\
\text { consumption }\end{array}$ & $\begin{array}{l}\text { The portion of the total freshwater input that has become } \\
\text { unavailable for reuse due to evaporative losses, } \\
\text { incoporation into the produced energy, or transfer to } \\
\text { another catchment or sea (the difference between the } \\
\text { total water withdrawal and the amount of water } \\
\text { released from the energy production system, i.e. } \\
\text { wastewater) }\end{array}$ \\
\hline Blue water & $\begin{array}{c}\text { The volume of freshwater (surface and/or groundwater) } \\
\text { consumed for energy production during its lifecycle }\end{array}$ \\
\hline Green water & $\begin{array}{l}\text { The volume of rainwater consumed (evapotranspirated } \\
\text { from land and vegetation) in the energy production } \\
\text { lifecycle }\end{array}$ \\
\hline Gray water & $\begin{array}{l}\text { An indicator of freshwater pollution, defined as the } \\
\text { volume of freshwater required to dilute pollutants } \\
\text { resulting from energy production during its lifecycle } \\
\text { to retain the quality of water above the agreed water } \\
\text { quality standards }\end{array}$ \\
\hline Virtual water & $\begin{array}{l}\text { The volume of water consumed and polluted for } \\
\text { producing energy, measured over the full energy } \\
\text { production lifecycle (sum of the blue, green and gray } \\
\text { water of energy production) }\end{array}$ \\
\hline Water footprint & $\begin{array}{l}\text { The geographically explicit indicator of the virtual water } \\
\text { content of energy, specifying the location of the water } \\
\text { footprint, water source, and the timing of use }\end{array}$ \\
\hline
\end{tabular}

community has mainly shown interest in assessing the amount of water withdrawn and consumed for energy production, while there has been less interest in the evaluation of the water quality and temperature effects of energy production despite the fact that these effects can be quite significant. For example, in the assessment of the water footprint of the electricity sector in the US, it was found that an average kilowatt-hour of electricity in the US in 2009 required almost 159 liters (42 gallons) of water, more than $95 \%$ of which was gray water footprint [79], which is associated with the water quality effects of electricity production.

Although some metrics such as water consumption and withdrawal have been used more frequently than others, this research area still suffers from the lack of consistent terminology [80] and a standard framework for assessing and measuring the water impacts of energy $[2 \bullet \bullet$. This has caused irresponsible, inconsistent and interchangeable use of some metrics, such as water withdrawal, water consumption and water footprint, despite their fundamental differences. Water use (utilization) is perhaps the most poorly defined water impact assessment metric, which has been equated to water withdrawal most of the time but has also been used as an equivalent of water consumption. Similarly, virtual water content [81, 82] and water footprint [82] have been used interchangeably with no clear understanding of their major distinction [77].

Inconsistency, to some extent, could be understood as a result of different interpretations and/or rephrasings. Nevertheless, it turns into a serious problem when fundamental underlying assumptions vary between these seemingly interchangeable terms. The existing inconsistencies in interpretation and application of the relevant terminologies and methods in different 'water for energy' studies create a significant uncertainty in comparability of their results and can be misleading to decision makers.

b. There is no superior method for evaluating the water impacts of energy. The existing literature $[70,73,80]$ reveals the tendency to compete for inventing the 'best' method for assessing the water impacts of energy. It has been argued that developing a 'correct' definition of sustainability is impossible as our understanding of sustainability is continuously evolving based on our better understanding of the complexities and interconnections of different sectors within the complex, coupled natural-human systems [83]. Similarly, developing the 'best' and 'correct' method for comprehensive assessment of the water impacts of energy production is impossible and unnecessary as our understanding of the water-energy nexus, its complexity, and its relations with the other sectors changes all 
the time. Selective application of water impact evaluation metrics can result in conflicting and misleading insights. For example, energy production through a certain method might have a low water consumption but a higher footprint. Reporting the water consumption information and overlooking the water footprint information can result in developing inappropriate policies.

Each metric and indicator has its own merits and shortcomings. Indicators can provide valuable and complementary information to guide decision making but they are hardly sufficient for providing a holistic understanding of the problem and making the best decisions. Instead of developing and finding the best method, the community must focus on the end goaldeveloping methods and solutions that can reduce the water impacts of energy production without unintended consequences and impacts on other sectors.

c. There is value in simplicity. The main reason for the success and popularity of metrics such as water withdrawal, water consumption, virtual water content and water footprint is their simplicity, which makes them understandable for a wider research community and the decision makers. These metrics try to quantify the impacts on water resources in volumetric terms, making them easier to understand, compare and balance. On the contrary, sophisticated methods that are based on too many assumptions require a lot of information and involve weighting and aggregation (e.g. Pfister and Hellweg [73]), and produce results that are questionable, controversial, and harder to interpret and explain [70].

d. Lack of data does not justify hidden assumptions and method misuse. Measurement of the water impacts of energy production based on each metric requires unique sets of data which might not be readily available. In the absence of such data and based on the specifications of studied cases, certain assumptions are made during calculations that may have substantial implications, affecting the final outcome. However, these assumptions usually remain concealed when reporting the results or when the results of different studies are compared with one another, even when such studies do not have consistent assumptions. For example, Hadian and Madani [2••] point to the significant differences between the water consumption estimations of the IEA and World Energy Council (WEC), attributing the differences to inconsistent assumptions that have not been explicitly reported and make it hard to judge which sets of estimations are more accurate and reliable.

In some cases, certain assumptions fundamentally change the metric being used, while this change is not reported, resulting in misleading information and conclusions. For example, in order to calculate the virtual water content of an energy, one might assume that the gray and green water footprints are equal to zero due to the lack of data, setting the resulting virtual content equal to the blue water footprint of that energy or simply its water consumption. Reporting the final outcome as a virtual water or water footprint rather than water consumption or blue water footprint is a methodological fallacy, and is inappropriate and misleading. The literature should be more explicit about the assumptions and limitations associated with different evaluations, and must be more cautious about certain assumptions that might change one metric to another.

e. System boundaries matter. To be informative and useful, assessment of the energy production impacts on water resources should fully consider all components of the energy production lifecycle. While the water used for cooling might be the major component of water use in the production of certain energies $[4 \cdot \bullet, 21 \bullet]$, one should not overlook the water impacts of energy technology production, energy production facility development and the gray water footprint of energy production, which can be highly significant [79].

The boundaries of lifecycle assessment must be reported to make the assessment results informative. In addition, depending on the production process and the applied technology, water impacts can vary significantly, even for the same energy source. Therefore, one needs to be cautious about using and comparing the results of studies that simply report the water impact of energies using a certain metric without reporting the lifecycle analysis boundaries and/or providing a full description of the studied energy production process.

f. Geographical boundaries matter. Similar to lifecycle analysis boundaries, geographical boundaries of the analysis might have significant impacts on the final outcome and must not be overlooked. For example, the green water footprint of biofuels and blue water footprint of hydropower can vary based on regional climate. Comparison of the water impacts of energies should be carried out using consistent and comparable geographic scales.

g. Balancing the water impacts of an energy source against its greenhouse gas emission reduction benefits does not make it sustainable. Evaluation of the water impacts of energy production is an essential step to better understanding of the water-energy nexus. Previous 'water for energy' studies have taught us that some renewable energies (e.g. concentrated solar power, biofuels and hydroelectricity) can be highly water-intensive $[14 \bullet, 15 \bullet, 22$, 23•]. Thus, considering the trade-off between reductions in the carbon footprint of energies and their water impacts would be necessary [50] to ensure that our solutions to the 
climate change problems would not cause problems in the water sector $[2 \bullet \bullet]$. Nevertheless, we need to remember that the water-energy-climate nexus is just a part of the larger nexus between water, energy, food, climate, ecosystem, economy, society, and politics, etc. Therefore, the solutions developed based on our partial understanding of the interrelationships of the complex natural-human systems are not necessarily sustainable and might be associated with unintended consequences in other sectors or subsystems. Developing sustainable solutions must be based on a system of systems approach that enables us to develop a holistic understanding of the complex natural-human systems and all the involved trade-offs $[35 \cdot 83]$.

\section{Conclusions}

Understanding the interconnection and interdependence of water and energy has created a strong interest in exploring the water-energy nexus. Concerns over the increasing water needs of the energy sector in the water-scarce future have further increased interest in the 'water for energy' side of this nexus. Numerous indicators and metrics have been employed to measure the different types of energy impacts on water, and research in the field has been somewhat successful in raising the general awareness of the public and policy makers about the significant effects of energy production on water resources. While this level of interest in the subject is a positive sign, the lack of coherence among different efforts for understanding the water impacts of energy limits our capacity to properly compare and judge the results of previous studies.

Future research on evaluation of the energy impacts on water resources is expected to try to develop a unique and standard method for comprehensive evaluation of the water effects of energy, take advantage of the simpler metrics, apply them in a complementary way, consider the whole lifecycle, use proper boundaries, and be more explicit about the analysis limitations and assumptions. These strategies would help us, as a community, to facilitate the development of sustainable water and energy solutions that do not have unintended impacts on other sectors.

\section{Compliance with Ethics Guidelines}

Conflict of Interest Kaveh Madani and Sina Khatami declare that they have no conflict of interest.

Human and Animal Rights and Informed Consent This article does not contain any studies with human or animal subjects performed by any of the authors.

\section{References}

Papers of particular interest, published recently, have been highlighted as:

- Of importance

- Of major importance

1. Gleick PH. Water and energy. Ann Rev Energy Environ. 1994;19(1):267-99.

2.• Hadian S, Madani K. The water demand of energy: implications for sustainable energy policy development. Sustainability. 2013;5(11): 4674-87. First effort to estimate the current and future water footprint of the energy sector at a global level.

3. King CW, Holman AS, Webber ME. Thirst for energy. Nat Geosci. 2008;1(5):283-6.

4.• Sanders KT. Uncharted waters? The future of the electricity-water nexus. Environ Sci Technol. Epub 22 Dec 2014. doi:10.1021/ es504293b. A recent review of the literature dealing with water requirements of electricity production.

5. Halstead M, Kober T, Zwaan B. Understanding the energy-water nexus. ECN-E14-046. Energy Research Centre of The Netherlands (ECN); 2014.

6. Mo W, Zhang Q. Energy-nutrients-water nexus: integrated resource recovery in municipal wastewater treatment plants. J Environ Manag. 2013;127:255-67.

7. Stillwell AS, Hoppock DC, Webber ME. Energy recovery from wastewater treatment plants in the United States: a case study of the energy-water nexus. Sustainability. 2010;2(4):945-62.

8. Tyagi VK, Lo S-L. Sludge: a waste or renewable source for energy and resources recovery? Renew Sustain Energy Rev. 2013;25:70828.

9. Dubreuil A, Assoumou E, Bouckaert S, Selosse S, Mai"zi N. Water modeling in an energy optimization framework: the water-scarce Middle East context. Appl Energy. 2013;101(0):268-79.

10. Sanders KT, Webber ME. Evaluating the energy consumed for water use in the United States. Environ Res Lett. 2012;7(3):034034.

11. Sanders K, King C, Stillwell A, Webber M. Clean energy and water: assessment of Mexico for improved water services and renewable energy. Environ Dev Sustain. 2013;15(5):1303-21.

12.• Stillwell AS, King CW, Webber ME, Duncan IJ, Hardberger A. The energy-water nexus in Texas. Ecol Soc. 2011;16(1):2. An innovative study and one of the first studies in the field that investigates the twoway relationship between water and energy at the regional scale.

13. Tarroja B, AghaKouchak A, Sobhani R, Feldman D, Jiang S, Samuelsen S. Evaluating options for balancing the water-electricity nexus in California: part 2. Greenhouse gas and renewable energy utilization impacts. Sci Total Environ. 2014;497-498:711-24.

14. Gerbens-Leenes PW, van Lienden AR, Hoekstra AY, van der Meer TH. Biofuel scenarios in a water perspective: the global blue and green water footprint of road transport in 2030. Glob Environ Change. 2012;22(3):764-75. The first investigation of the future water demand changes related to a transition to biofuels in road transport at the global level.

15. Gerbens-Leenes W, Hoekstra AY. The water footprint of biofuelbased transport. Energy Environ Sci. 2011;4(8):2658-68. A forward-looking study that quantifies the water footprints of biofuel-based transport based on first-generation biofuels in different parts of the world.

16. King CW, Webber ME. Water intensity of transportation. Environ Sci Technol. 2008;42(21):7866-72.

17. Ackerman F, Fisher J. Is there a water-energy nexus in electricity generation? Long-term scenarios for the western United States. Energy Policy. 2013;59:235-41. 
18. Averyt K, Macknick J, Rogers J, Madden N, Fisher J, Meldrum J, et al. Water use for electricity in the United States: an analysis of reported and calculated water use information for 2008. Environ Res Lett. 2013;8(1):015001. An interesting study highlighting the significant difference of the estimated and reported water withdrawals and consumptive use of US power plants.

19. Dodder RS. A review of water use in the U.S. electric power sector: insights from systems-level perspectives. Curr Opin Cheml Eng. 2014;5(0):7.

20. Macknick J, Newmark R, Heath G, Hallett K. Operational water consumption and withdrawal factors for electricity generating technologies: a review of existing literature. Environ Res Lett. 2012;7(4):045802.

21. Meldrum J, Nettles-Anderson S, Heath G, Macknick J. Life cycle water use for electricity generation: a review and harmonization of literature estimates. Environ Res Lett. 2013;8(1):015031. Lifecycle assessment of water withdrawals and consumptive uses for renewable and non-renewable electricity generation technologies in the US

22. Gerbens-Leenes PW, Hoekstra AY, van der Meer T. The water footprint of energy from biomass: a quantitative assessment and consequences of an increasing share of bio-energy in energy supply. Ecol Econ. 2009;68(4):1052-60.

23. Mekonnen MM, Hoekstra AY. The blue water footprint of electricity from hydropower. Hydrol Earth Syst Sci. 2012;16(1):179-87. An assessment of the blue water footprint of hydroelectricity in different regions in the world, suggesting that hydroelectric generation through large dams is highly water consumptive.

24. Scott CA, Pierce SA, Pasqualetti MJ, Jones AL, Montz BE, Hoover $\mathrm{JH}$. Policy and institutional dimensions of the water-energy nexus. Energy Policy. 2011;39(10):6622-30.

25. King CW, Stillwell AS, Twomey KM, Webber ME. Coherence between water and energy policies. Nat Resour J. 2013;117-215.

26. Siddiqi A, Kajenthira A, Anadón LD. Bridging decision networks for integrated water and energy planning. Energy Strategy Rev. 2013;2(1):46-58.

27. Bazilian M, Rogner H, Howells M, Hermann S, Arent D, Gielen D, et al. Considering the energy, water and food nexus: towards an integrated modelling approach. Energy Policy. 2011;39(12):7896906.

28. Hanlon P, Madel R, Olson-Sawyer K, Rabin K, Rose J. Food, water and energy: know the nexus: GRACE Communications Foundation; 2013

29. Hoff H. Understanding the nexus: background paper for the Bonn 2011 Nexus Conference. Stockholm Environmental Institute (SEI); 2011.

30. Lee B, Preston F, Kooroshy J, Bailey R, Lahn G. Resources futures. The Royal Institute of International Affairs, Chatham House; 2012.

31. Villarroel Walker R, Beck MB, Hall JW, Dawson RJ, Heidrich O. The energy-water-food nexus: strategic analysis of technologies for transforming the urban metabolism. J Environ Manag. 2014;141: 104-15.

32. Waughray D. Water security: the water-food-energy-climate nexus. Report no.: 1597267368. World Economic Forum; 2011.

33. Hadian S, Madani K. New finance-based portfolio analysis framework for sustainable energy planning. World Environmental and Water Resources Congress 2014: Water without Borders; 1-5 Jun 2014; Portland (OR): ASCE.

34. Hadian S, Madani K, Gonzalez J, Mokhtari S, Mirchi A. Sustainable energy planning with respect to resource use efficiency: insights for the United States. World Environmental and Water Resources Congress 2014: Water without Borders; 1-5 Jun 2014; Portland (OR): ASCE.

35. Hadian S, Madani K. A system of systems approach to energy sustainability assessment: are all renewables really Green? Ecol Indic. 2015;52:194-206. doi:10.1016/j.ecolind.2014.11.029.
Multi-dimensional analysis of the water-energy-climate-landeconomy nexus which argues that a system of systems approach is necessary for developing sustainable energy solutions.

36. US Energy Information Administration (EIA-US). International energy outlook 2011. US Energy Information Administration; 2011.

37.• Rodriguez DJ, Delgado A, DeLaquil P, Sohns A. Thirsty energy. World Bank, Water Papers 78923. Washington, DC: The World Bank; 2013. The first publication of the World Bank's energywater initiative, examining the water requirements of power generation.

38. United Nations World Water Assessment Programme (WWAP). World Water Development Report 2014: Water and Energy. Paris: UNESCO; 2014.

39. World Energy Council. Water for energy: executive summary London: World Energy Council; 2010.

40. Food and Agricultural Organization of the United Nations. The state of land and water resources for food and agriculture (SOLAW): managing systems at risk. London: Food and Agricultural Organization of the United Nations; 2011.

41.• International Energy Agency. Water for Energy: Is energy becoming a thirstier resource? Excerpt from the World Energy Outlook: Chapter 17. International Energy Agency; 2012. IEA's estimation of the water consumption and water withdrawals of the world's energy sector in 2035, proving that the energy sector would become thirstier in the future.

42. Byers EA, Hall JW, Amezaga JM. Electricity generation and cooling water use: UK pathways to 2050. Glob Environ Change. 2014;25(0):16-30. An assessment of the current and future water abstraction and consumption by the UK's thermoelectric sector, arguing that future reliance on nuclear energy and carbon capture and storage can increase water use.

43. Fry M, Hoeinghaus DJ, Ponette-González AG, Thompson R, La Point TW. Fracking vs faucets: balancing energy needs and water sustainability at urban frontiers. Environ Sci Technol. 2012;46(14): 7444-5.

44. Guo M, Xu Y, Chen YD. Fracking and pollution: can China rescue its environment in time? Environ Sci Technol. 2014;48(2):891-2.

45. Mauter MS, Alvarez PJJ, Burton A, Cafaro DC, Chen W, Gregory $\mathrm{KB}$, et al. Regional variation in water-related impacts of shale gas development and implications for emerging international plays. Environ Sci Technol. 2014;48(15):8298-306.

46. Nicot J-P, Scanlon BR. Water use for shale-gas production in Texas, U.S. Environ Sci Technol. 2012;46(6):3580-6.

47. Small MJ, Stern PC, Bomberg E, Christopherson SM, Goldstein $\mathrm{BD}$, Israel $\mathrm{AL}$, et al. Risks and risk governance in unconventional shale gas development. Environ Sci Technol. 2014;48(15):8289 97.

48. Vengosh A, Jackson RB, Warner N, Darrah TH, Kondash A. A critical review of the risks to water resources from unconventional shale gas development and hydraulic fracturing in the United States. Environ Sci Technol. 2014;48(15):8334-48.

49. Mirchi A, Hadian S, Madani K, Rouhani OM, Rouhani AM. World energy balance outlook and OPEC production capacity: implications for global oil security. Energies. 2012;5(8):2626-51.

50. Dalla Marta A, Natali F, Mancini M, Ferrise R, Bindi M, Orlandini S. Energy and water use related to the cultivation of energy crops: a case study in the Tuscany region. Ecol Soc. 2011;16(2):2.

51. Fingerman KR, Torn MS, O'Hare MH, Kammen DM. Accounting for the water impacts of ethanol production. Environ Res Lett. 2010;5(1):014020.

52. Gohari A, Eslamian S, Mirchi A, Abedi-Koupaei J, Massah Bavani A, Madani K. Water transfer as a solution to water shortage: a fix that can backfire. J Hydrol. 2013;491:23-39.

53. Gleeson T, Wada Y, Bierkens MFP, van Beek LPH. Water balance of global aquifers revealed by groundwater footprint. Nature. 2012;488(7410):197-200. 
54. Madani K. Water management in Iran: what is causing the looming crisis? J Environ Stud Sci. 2014;4(4):315-28.

55. Shah T, Roy AD, Qureshi AS, Wang J. Sustaining Asia's groundwater boom: an overview of issues and evidence. Nat Resour Forum. 2003;27(2):130-41.

56. Amarasinghe UA, Smakhtin V. Water productivity and water footprint: misguided concepts or useful tools in water management and policy? Water Int. 2014:1-18.

57. Blasing T, Sullivan A, Madani K. Response of California summer hydroelectricity generation to spring temperature. Br J Environ Clim Change. 2013;3(3):316-32.

58. Jamali S, Abrishamchi A, Madani K. Climate change and hydropower planning in the Middle East: implications for Iran's Karkheh hydropower systems. J Energy Eng. 2013;139(3):153-60.

59. Madani K, Guégan M, Uvo CB. Climate change impacts on highelevation hydroelectricity in California. J Hydrol. 2014;510:15363.

60. Guégan M, Uvo CB, Madani K. Developing a module for estimating climate warming effects on hydropower pricing in California. Energy Policy. 2012;42:261-71.

61. Gohari A, Eslamian S, Abedi-Koupaei J, Massah Bavani A, Wang D, Madani K. Climate change impacts on crop production in Iran's Zayandeh-Rud river basin. Sci Total Environ. 2013;442:405-19.

62. Kurukulasuriya P, Rosenthal S. Climate change and agriculture: a review of impacts and adaptations. Contract no. 91. Washington, DC: The World Bank Environment Department; 2003.

63. Msowoya K, Davtalab R, Madani K. Climate change impacts on rainfed corn production in Malawi's Lilongwe district. World Environmental and Water Resources Congress 2014: Water without Borders; 1-5 Jun 2014; Portland (OR).

64. Bayart J-B, Bulle C, Deschênes L, Margni M, Pfister S, Vince F, et al. A framework for assessing off-stream freshwater use in LCA. Int J Life Cycle Assess. 2010;15(5):439-53.

65. Cohen E, Ramaswami A. The water withdrawal footprint of energy supply to cities. J Ind Ecol. 2014;18(1):26-39.

66. US Department of Energy National Energy Technology Laboratory (DOE/NETL). Estimating freshwater needs to meet 2025 electricity generating capacity forecasts. US Department of Energy; 2004.

67.• US Department of Energy National Energy Technology Laboratory (DOE/NETL). Estimating freshwater needs to meet future thermoelectric generation requirements. US Department of Energy; 2011. An estimation of freshwater withdrawal and consumption requirements of the US thermoelectric generation sector in the future.
68. Elena G-d-C. Esther V. From water to energy: the virtual water content and water footprint of biofuel consumption in Spain. Energy Policy. 2010;38(3):1345-52.

69. Hill R, Younos T. The intertwined tale of energy and water. Blacksburg (VA): Virginia Water Resources Research Center; 2007.

70. Hoekstra AY, Gerbens-Leenes W, van der Meer TH. Reply to Pfister and Hellweg: Water footprint accounting, impact assessment, and life-cycle assessment. Proc Natl Acad Sci U S A. 2009;106(40):E114-E.

71. Jacobson MZ. Review of solutions to global warming, air pollution, and energy security. Energy Environ Sci. 2009;2(2):148-73.

72. Núñez M, Pfister S, Antón A, Muñoz P, Hellweg S, Koehler A, et al. Assessing the environmental impact of water consumption by energy crops grown in Spain. J Ind Ecol. 2013;17(1):90-102.

73. Pfister S, Hellweg S. The water "shoesize" vs. footprint of bioenergy. Proc Natl Acad Sci U S A. 2009;106(35):E93-E4.

74. Siddiqi A, Anadon LD. The water-energy nexus in Middle East and North Africa. Energy Policy. 2011;39(8):4529-40.

75. Torcellini PA, Long N, Judkoff R. Consumptive water use for US power production: National Renewable Energy Laboratory; 2003.

76. Varbanov PS. Energy and water interactions: implications for industry. Curr Opin Cheml Eng. 2014;5(0):15-21.

77. Velázquez E, Madrid C, Beltrán M. Rethinking the concepts of virtual water and water footprint in relation to the productionconsumption binomial and the water-energy nexus. Water Resour Manag. 2011;25(2):743-61.

78. Zhang C, Anadon LD. Life cycle water use of energy production and its environmental impacts in China. Environ Sci Technol. 2013;47(24):14459-67. A valuable effort to estimate the lifecycle water withdrawals, consumptive water use and wastewater discharge of the energy sector in China.

79. Wilson W, Leipzig T, Griffiths-Sattenspiel B. Burning our rivers: the water footprint of electricity. Portland, Oregon: River Network; 2012.

80. Berger M, Finkbeiner M. Water footprinting: how to address water use in life cycle assessment? Sustainability. 2010;2(4):919-44.

81. Allan T. Moving water to satisfy uneven global needs: "trading" water as an alternative to engineering it. ICID J. 1998;47(2):1-8.

82. Hoekstra AY, Chapagain AK, Aldaya MM, Mekonnen MM. The water footprint assessment manual: setting the global standard. London: Earthscan; 2011.

83. Hjorth P, Madani K. Sustainability monitoring and assessment: new challenges require new thinking. J Water Resour Plan Manag. 2014;140(2):133-5. 